\title{
POLITIKA
}

\section{PARTINIŲ SISTEMŲ STABILUMO SAMPRATA IR MATAVIMAS: LIETUVOS SITUACIJA 1990-2010 METAIS}

\author{
MAŽVYDAS JASTRAMSKIS
}

Vilniaus universiteto Tarptautiniu santykiu ir politikos mokslu institutas, doktorantas

The Institute of International Relations and Political Science of Vilnius University, Ph. D. Candidate

Vokiečiu g. 10, LT-01130 Vilnius

El.paštasmazvydas.jastramskis@gmail.com

\section{Santrauka}

Straipsnyje analizuojamas Lietuvos partinès sistemos stabilumas 1990-2010 metais trijuose lygmenyse: rinkimu, parlamento ir vyriausybès. Matuojant ši reiškini remiamasi Mogenso N. Pederseno, Peterio Mairo ir Giovannio Sartorio suformuotais tyrimo instrumentais, ịvertinant ju trūkumus ir patobulinant.

Daroma išvada, kad ilgainiui Lietuvos partine sistema tapo nestabili visuose lygmenyse. Pirma, aukštas rinkimu nestabilumas pastebimas per visa 1990-2010 m. laikotarpi. Antra, Lietuvos partineje sistemoje taip ir nepavyko isitvirtinti nuosaikaus daugiapartizmo tipui. Trečia, konkurencijos dèl vyriausybès vietu struktūra po $2000 \mathrm{~m}$. tapo visiškai destabilizuota. Be to, straipsnyje patvirtinama, kad partines sistemos stabilumas yra daugiadimensinis reiškinys.

Reikšminiai žodžiai: partinè sistema ir jos stabilumas; rinkèjų elgsenos kaitumas; partijų pakeitimas; fragmentacija; ideologinis atstumas; reikšminga partija; poliarizacija; antisisteminè partija; konkurencija dèl vyriausybès vietų. 


\section{1. İvadas. Kodèl svarbu tirti partinių sistemų stabilumą?}

Partinès sistemos yra svarbi demokratinių politinių sistemų dalis ir kriterijus, pagal kurị kartais vertinama pati demokratija. Tam tikri partinès sistemos parametrai ir jų stabilumas gali būti traktuojami kaip palankūs veiksniai apskritai visam politinio proceso stabilumui ir efektyvumui užtikrinti. Tokiais bruožais kaip didelè fragmentacija, dažna reikšmingu partijų kaita, nuolatos besikeičiantys konkuruojantys blokai pasižyminti partinè sistema gali būti viena iš pagrindinių platesnio politinio nestabilumo (pvz., dažnas vyriausybių žlugimas) ar net neefektyvaus ekonomikos problemų sprendimo priežastimi. Iš palyginti naujų konkurencinių partinių sistemų tai itin ryšku Serbijoje, kur daugybės mažų ir ideologiškai neapibrèžtų „išvalymas“ iš partijų politinès sistemos minimas kaip būtina sąlyga, siekiant didesnio ilgalaikio politinio stabilumo. ${ }^{1}$

Kodèl partinių sistemų stabilumo tyrimai yra reikšmingi konkrečiai parlamentarizmo studijoms? Pirmiausia reikètų akcentuoti, kad parlamentas yra viena iš kertinių demokratinès politinės sistemos institucijų. Remiantis Alvidu Lukošaičiu, partinès sistemos nestabilumo požymiai (nuolatinis partijų skaidymasis, naujų reikšmingų politinių jègų radimasis, fragmentacijos augimas) neigiamai veikia parlamento institucijos funkcionavimą. ${ }^{2}$ Iš tiesų, kuo dažniau keičiasi politinès jègos ir jų sąveikų šablonai partinèje sistemoje, tuo sunkiau prognozuoti jų bendradarbiavimo ir priešpriešos santykius parlamento arenoje. Kuo daugiau partinëje sistemoje reikšmingų politinių jẻgų, tuo sunkiau užtikrinti efektyvų parlamento darbą dèl parlamento frakcijų fragmentacijos.

Akivaizdu, kad partinès sistemos parametrai ir stabilumas glaudžiai susiję su įstatymų leidžiamąja valdžia. Efektyviam parlamento darbui yra itin svarbi stabili partinè sistema, kurios struktūra ir veikejjų tarpusavio

1 Djurkovic, M. Political parties in Serbia: Source of Political instability. Watchfield: Defence Academy of the United Kingdom, Conflict studies research centre, 2006, p. 1-2.

2 Lukošaitis, A. Lietuviškasis parlamentarizmas ir Seimo rinkimų pralaimètojai. Lietuva po Seimo rinkimu 2008. Sudare A. Jankauskas. Vilnius: Vilniaus universiteto leidykla, p. 42. 
santykiai būtų daugiau ar mažiau prognozuojami. Ar per 20 Nepriklausomybės metų kada nors buvome bent pradèję artèti prie idealios partinès sistemos modelio, o galbūt per abu dešimtmečius šis veiksnys Seimo darbo efektyvumui buvo itin nepalankus?

Straipsnio tikslas - ịvertinti Lietuvos partinès sistemos stabilumo raidą (kaip svarbų veiksnį efektyviam parlamento darbui) 1990-2010 metais, remiantis skirtingas partinių sistemų stabilumo dimensijas pabrèžiančiomis teorinèmis prieigomis. Straipsnyje laikomasi prielaidos, kad partinių sistemų stabilumas negali būti tiksliai ịvertintas taikant tik vieną tyrimo instrumentą (pvz., rinkejjų elgsenos kaitumą), nes partinė sistema funkcionuoja keliuose lygmenyse: rinkimu, parlamento ir vyriausybès. Siekiant parodyti, kad stabilumo reiškinys yra daugiadimensinis, aptariami ir ịvertinami skirtingoms teorinems prieigoms atstovaujantys tyrimo instrumentai bei siūlomos jų tobulinimo galimybès. Vèliau, taikant šiuos instrumentus, siekiama aiškiai išskirti Lietuvos partinės sistemos stabilumo raidos etapus pagal šias dimensijas ir išsiaiškinti, ar stabilumas skirtinguose lygmenyse susijęs?

Straipsnio tikslo siekiama igyvendinant tris pagrindinius uždavinius, kurie atitinka tolesnę straipsnio skyrių struktūrą: 1) apibrèžti partinès sistemos sąvoką; 2) pateikti partinès sistemos stabilumo sampratą ir matavimo būdus; 3) pritaikyti suformuotus tyrimo instrumentus Lietuvos partinès sistemos situacijai 1990-2010 metais. Formuojant partinès sistemos stabilumo sampratą ir matavimo instrumentus remiamasi Mogenso N. Pederseno, Peterio Mairo ir Giovannio Sartorio darbais, taip pat jų idejjas plètojusių ir kritikavusių autorių (Alano Sikko, Giovannio Capoccia) idejomis. İvertinant Lietuvos partinès sistemos stabilumą remiamasi šią problematiką tyrinèjusių autorių (Alvido Lukošaičio, Jūratès Novagrockienès ir kitų) darbais.

\section{Partinès sistemos sąvoka}

Partinių sistemų stabilumo samprata ir matavimas natūraliai turi atsiremti ị sąvokos „partinè sistema“ apibrèžimą. Akivaizdu, kad tai, kaip suvokiame partinès sistemos reiškini, yra tiesiogiai susiję su jos stabilumo tyrimu. 
Plačiąja prasme partinè sistema demokratinejje politinejje sistemoje galètų būti suvokiama kaip apskritai visų partijų ${ }^{3}$, įregistruotų remiantis demokratiniais įstatymais, visuma. Tačiau kiekvienoje valstybeje egzistuoja daug partijų, kurios, nepaisant faktinio egzistavimo, šalies politineje arenoje arba apskritai nereikšmingos, arba turi tik minimalią ịtaką (pvz., jų kandidatai kartais išrenkami $\mathfrak{i}$ tam tikrų savivaldos vienetų valdžios organus). ${ }^{4}$ Tokių politinių jègų ịtraukimas ị partinès sistemos apibrèžimą faktiškai atimtų iš tyrèjo galimybę daryti skirtis tarp konkrečių valstybių partinių sistemų.

Kitaip tariant, būtina akcentuoti vieną fundamentaliausių partinių sistemų tyrimų teiginių, suformuluotą G. Sartorio - partinei sistemai reikètų priskirti tik reikšmingas partijas, o ne apskritai visas šalyje įregistruotas ir rinkimuose dalyvaujančias politines jègas. Reikšminga partija yra politinè jèga, turinti arba patekimo i̇ vyriausybę, arba šantažo (angl. blackmail) potencialą. Šantažo potencialas susijęs su situacija, kai partija realiai nèra minima kaip potenciali koalicijos partneré, tačiau „jos buvimas arba atsiradimas paveikia vyriausybinès orientacijos partijų partinès konkurencijos taktiką" (šie teiginiai bus išplètoti kitame skyriuje, išsamiau pristatant G. Sartorio teoriją - tačiau jais remiamasi visame straipsnyje). ${ }^{5}$

Kita vertus, taip pat būtina pastebėti, jog dalių (partijų) visuma dar nereiškia tam tikros sistemos egzistavimo: „Partijų tyrinėtojai vieningai sutaria, kad partinè sistema apibréžiama ne paprasta ją sudarančių elementų suma, o kaip politinių partijų, veikiančių vienoje šalyje pagal organizuotą modelį, sąranga“. ${ }^{6}$ Dažniausiai yra taikomas G. Sartorio suformuluotas požiūris ị partinę sistemą, kuris akcentuoja būtent „sistemos“

3 Darbe laikomasi konvencinès nuostatos, kad partija yra organizacija, kurią nuo kitų visuomeninių organizacijų, lobistinių grupių ir kt. skiria dalyvavimas rinkimuose į politinę valdžią.

4 Lietuvoje puikus tokios politinès jẻgos pavyzdys - dabartine Lietuvos centro partija, kurios nariai dominuoja Varėnos savivaldybejje, tačiau parlamente jai neatstovaujama.

5 Sartori, G. Lyginamoji konstituciné inžinerija. Kaunas: Poligrafija ir informatika, 2001, p. 50.

${ }^{6}$ Novagrockienè, J. Politinių partijų ir partinių sistemų analizès metodologiniai pagrindai. Lietuvos politinès partijos ir partine sistema (1 knyga). Sudarè A. Jankauskas, E. Kūris ir J. Novagrockienè. Kaunas: Naujasis lankas, 1997, p. 22. 
kategoriją. Anot šio autoriaus, egzistuoja du svarbūs sistemos požymiai: pirma, sistema turi savybes, kurių neturi atskiri ją sudarantys elementai; antra, sistema traktuojama kaip padarinys tam tikrų sąveikos šablonų (ir yra neatsiejama nuo jų) tarp ją sudarančių dalių; šie šablonai suformuoja sistemos ribas ar bent jau kontūrus. ${ }^{7}$

Taigi, partinè sistema turètų būti atskiriama teoriniu lygmeniu kaip autonomiška sistema, kurią geriausiai apibūdina sąveikų tarp ją sudarančių dalių (reikšmingų partijų) visumos modelis. Prieš pradedant gilintis ì partinių sistemų stabilumo ir nestabilumo specifiką, būtina pabréžti šio aspekto svarbą: jeigu stabilumą traktuojame kaip tam tikro reiškinio fundamentalių požymių išsilaikymą (o nestabilumą - to antiteze), jị fiksuodami dèmesị pirmiausia turime kreipti ị tik pačiai sistemai būdingus bruožus, taigi - $\mathfrak{i}$ konkrečius jos sąveikų šablonus (jie bus detalizuoti vèliau).

Toks partinès sistemos apibrèžimas leidžia išvengti grèsmès tiriant partinès sistemos stabilumą pervertinti konkrečių jos veikejjų pozicijų stabilumą. Pavyzdžiui, tokioje konkurencinejje partinèje sistemoje, kurioje viena partija po kiekvienų rinkimų vis gauna pakankamai parlamento vietų, kad galètų viena formuoti vyriausybę, egzistuoja specifinis stabilumas - nuolatinis vienos politinès jègos dominavimas. Tačiau šis verdiktas nieko nepasako apie likusių reikšmingų partijų padètị tiek dominuojančios partijos, tiek kitų sistemos veikejjų atžvilgiu. Ar egzistuoja kelios, nuolatos likusius balsus ir parlamento vietas persidalijančios partijos, o galbūt dominuojanti partija turi vieną rimtą konkurentą, kurio pozicijos stiprëja? Tokioje partinejje sistemoje bendras rinkejjų elgsenos kaitumas (išsamiau žr. kitame skyriuje) gali demonstruoti paviršutiniškam stabilumui priešingas tendencijas. Taigi, vertindami partinės sistemos stabilumą, turime ieškoti visai partinei sistemai bendrų savybių ir, prieš darydami galutinę išvadą, būtinai atsižvelgti ị ją sudarančių veikèjų sąveikų tendencijas.

Ten pat, p. 22-24; cituota iš Sartori, G. Parties and Party Systems: A Framework for Analysis. Cambridge: Cambridge University Press, 1976, p. 42-46. 


\section{Partinès sistemos stabilumo dimensijos ir matavimas}

Partinès sistemos stabilumas gali būti apibrèžiamas ịvairiai - iš esmès konceptualizavimo variantai atspindi skirtingas reiškinio dimensijas, aptariamas šiame skyriuje. Tik vienu matavimo instrumentu paremtas tyrimas pervertintų vieną konkrečią dimensiją. Tokioje situacijoje kyla pavojus gauti netikslius tyrimo rezultatus: pavyzdžiui, padaryti galutinę išvadą, kad partinè sistema nestabili, nors kitu aspektu (ị kurị tyrime neatsižvelgta) ji demonstruoja stabilizacijos tendencijas. Todèl, siekiant visapusiškai ịvertinti Lietuvos partinès sistemos situaciją 1990-2010 m., reikètų atsižvelgti ị visas svarbiausias stabilumo dimensijas. Partinès sistemos stabilumas gali būti įvertintas skirtinguose lygmenyse: a) rinkimų: kaip persiskirsto rinkejų balsai tarp partijų, kaip pasireiškia konkurencija rinkimų metu; b) parlamento arenos: kiek parlamento vietų turi reikšmingos partijos, kokia yra politinių jègų fragmentacija ir jos kaita; c) vyriausybės formavimo: kaip pasireiškia partijų konkurencija formuojant vyriausybines koalicijas, ar ji linkusi ị stabilius sąveikų šablonus.

Rinkëjų elgsenos kaitumas. Ivertinant partinès sistemos stabilumą dažniausiai yra taikomas rinkimų lygmens kintamasis - 1979 m. M. Pederseno pasiūlytas rinkejju elgsenos kaitumo matas. ${ }^{8}$ Tai standartinis kiekybinis metodas nustatant partinès sistemos(-u) stabilumą ${ }^{9}$, jis panaudotas daugelyje svarbių šios srities tyrimų. Pederseno matas „originalia forma" parodo rinkimų nestabilumą - kitaip tariant, bendrą visų partijų balsų, gautų per vienus parlamento rinkimus, pokytị, palyginti su praéjusiais rinkimais.

Po M. Pederseno straipsnio 1979 m. tyrèjai siūlè įvairių šio mato modifikacijų. Vis dèlto dažniausiai partinių sistemų stabilumo tyrimuose iki šiol naudojama originali bendros rinkejjų elgsenos kaitumo (angl. total volatility) mato (TV) formulè: „TV=|PiV $|+| \mathrm{PjV}|+| \mathrm{PkV}|+\ldots ..| \mathrm{PnV} \mid / 2 “$.

8 Pedersen, M.N. The Dynamics of European Party Systems: Changing Patterns of Electoral Volatility. European Journal of Political Research. 1979, No. 7, p. 1-26.

9 Sikk, A. Stabilisation of Post-Communist Party Systems: master tiesis. University of Tartu, Faculty of Social Sciences, Department of Political Science, p. 5. 
$\mathrm{PiV}$ - tai partijos $i$ gautų balsų per rinkimus pokytis, palyginti su naujausiais rinkimais (pvz., jeigu partija gavo 20 proc. balsų, o prieš tai buvusiuose rinkimuose 30 proc., jos individualus pokytis yra -10). ${ }^{10}$

Rinkejjų elgsenos kaitumo mato taikymas, ịvertinant partinès sistemos stabilumą, susijęs su keliomis problemomis. Pirma, mato taikymas komplikuojasi, kai partinė sistema pasižymi nuolatiniais partijų skilimais ir susiliejimais (angl. splits and mergers). Tai ypač būdinga pokomunistinèms Vidurio ir Rytų Europos regiono demokratijoms, tarp kurių Lietuva $\mathfrak{i}$ išimtis tikrai nepretenduoja: nuolatinė kaita ypač pastebima liberaliųjų ir krikščionių demokratų partijų sparnuose. Skaičiuojant rinkëjų elgsenos matą, partijų skilimų ir susiliejimų problema šiame straipsnyje sprendžiama taip: a) partijų susiliejimo atveju pokytis skaičiuojamas iš po susiliejimo sukurtos partijos balsų atėmus ją suformavusių partijų per praejusius parlamento rinkimus gautų balsų sumą; b) partijų skilimo atveju balsų pokytis skaičiuojamas atimant iš po skilimo susikūrusių politinių jègų balsų sumos iki skilimo egzistavusios partijos balsus: situacija, kai po skilimo neįmanoma tiksliai nustatyti vienos pagrindinès partijos, o nauji politiniai dariniai yra lygiaverčiai tiek politinio svorio, tiek ideologijos aspektais; c) jeigu nuo partijos atsiskiria tam tikra politikų grupė ir įkuriama nauja „separatistinè partija (pagrindiné partija toliau funkcionuoja tuo pačiu pavadinimu, o naujas politinis darinys nuo jos aiškiai skiriasi arba politine įtaka, arba ideologiškai), jos gauti balsai vertinami kaip pokytis (tai yra, jei nauja partija gavo 10 proc., pokytis yra 10 proc.).

Reikètų pastebėti, kad rinkèjų elgsenos kaitumo matas mažai ką pasako apie labiau konkrečias partinès sistemos stabilumo rinkimų lygmenyje problemas, susijusias su reikšmingų partijų kaita: ar balsai persidalijami daugiausia tarp partinejje sistemoje ịsitvirtinusių veikejjų? O galbūt jie nuolatos prarandami naujoms politinèms jègoms? Atsižvelgiant ị tai, verta šalia M. Pederseno mato, kuris parodo apskritai bendrą balsų per-

${ }^{10}$ Pennings, P., Keman, H., Kleinnijenhuis, J. Doing Research in Political Science: an introduction to comparative methods and statistics. London: Sage Publications, 1999, p. 229-230. 
skirstymą tarp partijų (tiek senųjų, tiek naujųjų), papildomai pateikti partiju pakeitimo (angl. party replacement) matą ${ }^{11}$, kuris parodytų, kiek procentų rinkèjų balsų surinko iki konkrečių rinkimų politinèje sistemoje neveikusios politinès jègos (tokiomis laikomos arba ankstesnejje pastraipoje prie „C“ kriterijaus apibūdintos „separatistinès“ partijos ${ }^{12}$, arba „tuščioje vietoje“ - tai yra iš naujo sukuriant visą partijos organizaciją ir narių tinklą - ikurtos politinès jègos) ${ }^{13}$. Tokiu atveju, jei po skilimo susikuria lygiavertès (ideologiškai ir ịtakos atžvilgiu) politinès jègos, jų gauti balsai, skaičiuojant partijų pakeitimo matą, neittraukiami.

Antrajame straipsnio skyriuje akcentuota, kad partinei sistemai reikètų priskirti tik reikšmingas partijas, tačiau taikant rinkèjų elgsenos kaitumo matą, i̇skaičiuojami visų rinkimuose dalyvaujančių partijų gauti balsai. Ar tai neprieštarauja tyrimo logikai? Reikètų atsakyti neigiamai, nes skaičiuojant rinkejjų elgsenos kaitumo matą, didžiausią svarbą jame turi reikšmingų partijų balsų pokyčiai - nereikšmingų politinių jègų gautų balsų pokyčiai (dèl partijų menkos įtakos politinėje arenoje) būna marginalūs ir neiškreipia bendro stabilumo įvertinimo. Kita vertus, jeigu nereikšminga partija per tam tikrus parlamento rinkimus tampa reikšminga, tai natūraliai padaro didesnę ịtaką rinkèjų elgsenos kaitumo ivertinimui.

Žinoma, nestabilumas rinkimų lygmenyje nebūtinai turi rodyti partinès sistemos nestabilumą kituose lygmenyse. P. Mairo atlikto partinių sistemų kaitos Vakarų demokratijose tyrimo rezultatai rodo, kad partinès sistemos stabilumas (kaita) ir elektorato stabilumas gali būti (ir dažniausiai yra) susiję, tačiau jie jokiu būdu nèra tapatūs reiškiniai. ${ }^{14}$ Tam tikrais periodais rinkejjų elgsenos kaitumas gali „pašokti“ $\mathfrak{i}$ iki tol nematytas

${ }^{11}$ Birch, S. Electoral Systems and Party System Stability in Post-Communist Europe. Paper prepared for presentation at the 97th annual meeting of the American Political Science Association. San Francisco, 2001, 30 August - 2 September, p. 4.

12 Pavyzdžiui, Liberalų demokratų partija (dabar - „Tvarka ir Teisingumas“), 2003 m. atskilusi nuo tuometinès Lietuvos liberalų sajungos.

${ }_{13}$ Pavyzdžiui, Naujoji sajunga (socialliberalai) ir Darbo partija.

${ }^{14}$ Mair, P. Party System Change: Approaches and Interpretation. Oxford: Clarendon Press, 1997, p. 215. 
aukštumas, tačiau partinè sistema išoriškai liks stabili, jos kiti parametrai nepasikeis, nes balsai bus persidalyti tarp tų pačių reikšmingų partijų. Todèl vertinant partinès sistemos stabilumą, kaip buvo akcentuota skyriaus pradžioje, reikètų atsižvelgti ir ị kitus partinès sistemos parametrus - jie įvertinami parlamento ir vyriausybès formavimo lygmenyse.

Fragmentacija ir ideologinis atstumas. Vertinant partinès sistemos stabilumą parlamento ir vyriausybès formavimo lygmenyse, verta prisiminti lyginamosios politikos klasiko G. Sartorio pasiūlytą partinių sistemų tipologiją. Remiantis juo, egzistuoja du pagrindiniai kriterijai, pagal kuriuos tipologizuojamos partinès sistemos, - tai fragmentacija ir ideologinis atstumas. Šių požymių kaitą trumpajame laikotarpyje galima traktuoti kaip partinès sistemos nestabilumą klasės/tipo ${ }^{15}$ atžvilgiu. Visgi, jeigu šie du požymiai išsilaiko - valstybès politinèje sistemoje yra îsitvirtinęs tam tikras stabilus partinès sistemos tipas/klasè.

Fragmentacija - tai reikšmingų (angl. relevant) politinių partijų skaičius šalies partinejje sistemoje. Šis kintamasis parodo, koks yra politinès galios sklaidos mastas: ar galia yra išsklaidyta, ar koncentruota. ${ }^{16}$ Jau buvo minèta, kad G. Sartoris nurodo dvi svarbiausias taisykles, pagal kurias partiją galima atmesti kaip nereikšmingą. Partija nelaikoma reikšminga, jeigu ji neturi bent vieno iš šių dviejų požymių: 1) vyriausybinio (koalicinio) potencialo; 2) šantažo potencialo. Pirmoji taisyklè nurodo situaciją, kai konkrečios partijos niekada neprireikia jokiai vyriausybinei koalicijai: nei dalyvavimo joje, nei paramos atžvilgiu. ${ }^{17}$ Vis delto kai kurios partijos, niekada neịtraukiamos ị vyriausybès formavimo procesą, kartais surenka penktadalị ar net daugiau rinkejjų balsų (tokių politinių jègų pavyzdžiai: Prancūzijos ir Italijos istorinès komunistų partijos, dabartinė Bohemijos ir Moravijos komunistų partija Čekijoje).

Kaip nurodo G. Sartoris, nors tokių partijų vyriausybinis potencia-

15 Remiantis G. Sartoriu, klasifikacija - kai skirstoma pagal vieną požymị, tipologizavimas - skirstymas pagal daugiau nei vieną požymį.

${ }^{16}$ Sartori, G. Parties and Party Systems: A Framework for Anglysis. Essex: ECPR Press, 2005 , p. 113.

${ }^{17}$ Ten pat, p. 108. 
las teoriškai lygus nuliui, jas atmesti kaip nereikšmingas būtų absurdiška. Todèl reikalinga papildoma, antroji, reikšmingų partijų skaičiavimo taisykle. ${ }^{18}$ Šantažo potencialas nurodo situaciją, kai politinès jègos egzistavimas ar atsiradimas veikia kitų partijų konkurencijos taktiką - ir ypač tada, kai tai pakeičia konkurencijos kryptị, kuri gali būti ịcentrinè (orientuota i partinès sistemos centrą) ar išcentrinè (orientuota ị kairès-dešinès polius partinejje sistemoje). ${ }^{19}$ Konkurencijos kryptị sunku išmatuoti, todèl G. Sartoris pažymi, kad šantažo potencialas iš esmès lygus veto galiai parlamento arenoje - tai yra, kai partija geba daryti itaką istatymų prièmimo procesui. ${ }^{20}$

Pagal fragmentacijos kriterijų G. Sartoris teoriniame lygmenyje išskiria 7 skirtingas partinių sistemų klases: vienpartinès, partijos-hegemonès, dominuojančios partijos, dvipartinès, riboto daugiapartiškumo, ekstremalaus daugiapartiškumo ir atomizuoto daugiapartiškumo. ${ }^{21}$ Tiksli skirtis tarp riboto ir ekstremalaus daugiapartiškumo G. Sartorio darbuose nenurodoma, - remiantis autoriumi, jis yra, kai veikia 5-6 reikšmingos partijos. ${ }^{22}$ Straipsnyje partinè sistema bus traktuojama kaip peržengusi nuosaikaus daugiapartiškumo ribą, jeigu joje yra daugiau nei 6 reikšmingos partijos (griežtesnis G. Sartorio kriterijaus variantas). Atomizuoto daugiapartiškumo atveju partijų skaičiavimas praranda prasmę, kai partinejje sistemoje yra daugiau kaip 10 reikšmingų partijų ir nė viena iš jų neturi svaresnès ịtakos viena kitai.

Antrasis tipologijos kriterijus - partinès sistemos mechanika - nuro-

18 Ten pat.

${ }^{19}$ Ten pat.

${ }^{20}$ Geras šantažo potencialo išpildymo pavyzdys, keičiant partijų konkurencijos krypti - klasikinès komunistų ir neofašistinių pažiūrų partijos Vakaruose (pvz., Italijoje), kurios atimdavo balsus iš centro partijų, o partinèje sistemoje nuolatos vykdavo balsų ,nutekèjimas“ iš centro į kraštutinę dešinę ir kairę. Icentrinès konkurencijos pavyzdys - Didžiosios Britanijos partinè sistema, kur leiboristų ir konservatorių partijos visuomet kovoja dèl centro rinkèjų.

${ }^{21}$ Sartori, G. Parties and Party Systems: A Framework for Anglysis. Essex: ECPR Press, 2005, p. 105-113.

${ }^{22}$ Sartori, G. A Typology of Party Systems. The West European Party System. Edited by Peter Mair. Oxford: Oxford University Press, 1990, p. 325. 
do, koks partinèje sistemoje įsitvirtinęs partijų konkurencijos modelis ir kokiomis kryptimis ta konkurencija orientuota. Partinès sistemos mechaniką žymi ideologinis atstumas tarp dviejų toliausiai konkurencinejje erdvejje nutolusių polių - reikšmingų partijų. Pagrindinis šio kriterijaus analitinis pranašumas - jis padeda atskirti poliarizuotas ir nepoliarizuotas partines sistemas. Mažo ideologinio atstumo (nepoliarizuotos) sistemos funkcionavimas pasižymi įcentrine konkurencija tarp dviejų pagrindinių polių. Didelio ideologinio atstumo (poliarizuotos) sistemos veikimo esminiai požymiai - išcentrinẻ konkurencija, keleto polių konkurencinèje erdvejje egzistavimas.

Kaip atskirti poliarizuotas sistemas nuo nepoliarizuotu, tai yra - kaip matuoti poliarizaciją? Du pagrindiniai poliarizuotos partinès sistemos indikatoriai yra reikšmingų antisisteminių partijų ir abipusių (angl. bilateral) opozicijų egzistavimas. ${ }^{23}$ Anot G. Sartorio, geriausi antisisteminių partijų pavyzdžiai demokratijose - komunistinių ir neofašistinių pažiūrų politinès jègos. Visgi tai nèra vienintelès įmanomos antisisteminès partijos - reikètų skirti išsamų ir glaustą apibrèžimus. Minimalus reikalavimas, kad partija būtų priskirta tokiam tipui - delegitimizuojanti ịtaka (turima galvoje - režimui). Remiantis šiuo reikalavimu, prie antisisteminių partijų galima priskirti tiek klasikines protesto partijas (pvz., Norvegijos ir Danijos progreso partijas), tiek apskritai visas radikalia retorika pasižyminčias partijas. G. Sartoris pažymi, kad siauraja prasme antisisteminès partijos pasižymi specifine svetima (angl. extraneous) ideologija - egzistuojančiai politinei sistema yra keliama ideologiškai prieštaraujanti alternatyva (kitaip tariant, tokia partija siekia pakeisti ne valdžią, bet valdžios sistemą). ${ }^{24}$

Abipusès opozicijos yra antrasis poliarizuotos partinès sistemos bruožas. Anot G. Sartorio, kai egzistuoja vienpusė opozicija, nesvarbu, kiek vyriausybei priešišku partijų ją sudaro, - jos visos gali susijungti ir pasiūlyti save kaip

${ }^{23}$ Sartori, G. Parties and Party Systems: A Framework for Anglysis. Essex: ECPR Press, 2005, p. 116-128; Sartori, G. A Typology of Party Systems. The West European Party System. Edited by Peter Mair. Oxford: Oxford University Press, 1990, p. 328-330.

${ }^{24}$ Sartori, G. Parties and Party Systems: A Framework for Anglysis. Essex: ECPR Press, 2005, p. 117-118. 
alternatyvią valdžią. Poliarizuotoje sistemoje egzistuoja bent dvi opozicijos, kurios yra viena nuo kitos nepriklausomos ir negali tarpusavyje sujungti pajègų. ${ }^{25}$ Tokia situacija reiškia, kad partinei sistemai būdinga ne dvipolè (kaip dvipartinèse sistemose), bet daugiapolè konkurencijos struktūra.

Nors G. Sartorio teorijai (tiesa, vèlesniuose jo darbuose tobulintai) jau daugiau nei 30 metų, vieno iš dviejų jos tipologizavimo kriterijų (fragmentacijai) taikymas ir dabartiniu metu nesudètingas: abi G. Sartorio taisykles, pagal kurias atskiriamos reikšmingos partijos, galima nesunkiai pritaikyti bet kurioje konkurencingoje partinejje sistemoje. Vis dèlto poliarizacijos kriterijus jautresnis istoriniams veiksniams - atrodo, jog antisisteminių partijų (vienas iš dviejų pagrindinių poliarizuotos sistemos bruožų) sąvoka, ypač griežtaja prasme, gali kelti problemų. „Grynąa“ totalitarine ideologija pasižyminčių neofašistinių ir komunistinių partijų ịtaka demokratinèse šalyse pastaraisiais dešimtmečiais tapo minimali.

Taigi, reikalinga sąvoką peržiūrèti - ar apskritai ją galima taikyti dabartiniame partinių sistemų kontekste. G. Capoccia pažymi, kad antisisteminè partija - terminas, kuris ypač dažnai „tampomas“ (angl. stretched); ịvairių autorių darbuose jam suteikiamas gana skirtingas turinys. Antisisteminès partijos sąvokos klasifikacinė galia turètų būti išlaikyta, ypač atsižvelgiant, kad tai yra vienas iš G. Sartorio teorijos kertinių akmenų. Atmetus šią sąvoką kaip nereikalingą, partinių sistemų tipų tyrimai iš esmès vèl būtų redukuoti iki dvipartinių ir daugiapartinių sistemų distinkcijos. ${ }^{26}$

G. Capoccia minètas su sąvoka susijusias problemas siūlo spręsti antisistemines partijas skirstant pagal pozicijos režimo (priešiškumas esamai politinei sistemai, ideologinè alternatyva režimui, kuriame partija veikia) ir kitų partijų (ideologinès distancijos kairès-dešinès skalëje nuo kitų partijų, izoliuotumas partineje sistemoje) kriterijus. Pirmajj kriterijų autorius nurodo kaip „ideologini antisistemiškumą“; antrasis bruožas - „santykio antisistemiškumas“. ${ }^{27}$

${ }^{25}$ Ten pat, p. 118-119.

${ }^{26}$ Capoccia, G. Anti-System Parties: A Conceptual Reassessment. Journal of Theoretical Politics. 2002, vol. 14, No. 9, p. 11-13.

${ }^{27}$ Ten pat, p. 14-21. 
Santykio antisistemiškumas apibūdinamas trimis savybėmis: 1) partijos elektoratas konkurencinejje erdvejje nutolęs nuo kaimyninių partijų; 2) žemas koalicinis potencialas; 3 ) esamą vyriausybę, tradicines partijas potencialiai delegitimizuojantys pareiškimai (nors ir neorientuoti ị režimo pakeitimą), prieš kitas politines jègas nukreipta priešiška propaganda. ${ }^{28} \mathrm{G}$. Capoccia taikliai pažymi, kad visos šios trys savybès gali būti būdingos partijai, kuri iš esmès neturi ideologijos, priešingos pamatinèms demokratinès politinès sistemos vertybèms. ${ }^{29}$ Ideologinis antisistemiškumas - kai partijos ideologija iš esmès yra antidemokratinè, nukreipta prieš pamatinius liberaliosios demokratijos principus. Taigi šio autoriaus siūlomas metodas padeda atskirti „tikrąsias" antidemokratines partijas ir tas, kurios tiesiog santykinai nutolusios nuo kitų politinių jègų.

Su G. Sartorio teoriniu modeliu yra susijusi dar viena problema - tai, kaip fragmentuota ar poliarizuota partinè sistema, galima nustatyti tik tam tikrame laiko periode. Kitaip tariant, sunku yra apskaičiuoti fragmentaciją konkrečiais metais (galbūt dabar ị koalicijas neittraukiama partija po pusès metų bus pakviesta i̇ vyriausybinę koaliciją) bei palyginti fragmentacijos lygio svyravimus; lygiai taip pat įvertinti poliarizaciją i̇manoma tik atsižvelgiant ị partijų „antisisteminị “ elgesi per ilgesnį laiko periodą ir abipusių opozicijų išsilaikymą.

Norint pasiekti tikslesnių rezultatų, matuojant fragmentaciją papildomai galima taikyti dažniausiai naudojamą politinès galios partinèje sistemoje koncentracijos fiksavimo instrumentą - Laakso-Taagepera (toliau - L-T) efektyvių partijų skaičiaus indeksą ${ }^{30}$ Didelis jo įvertis žymi aukšto lygio fragmentaciją partinèje sistemoje, mažas - žemo lygio fragmentaciją. Laakso-Taagepera indekso skaičiavimas yra tapatus Herfindahlio indeksui ${ }^{31}$ (tai koncentracijos matas - nominalių kintamųjų duomenų sklaidos charakte-

${ }^{28}$ Ten pat, p. 15.

${ }^{29}$ Ten pat, p. 16.

${ }^{30}$ Molinar, J. Counting the Number of Parties: An Alternative Index. The American Political Science Review. 1991, vol. 85, No. 4, p. 1383.

${ }^{31}$ Pennings, P., Keman, H., Kleinnijenhuis, J. Doing Research in Political Science: an introduction to comparative methods and statistics. London: Sage Publications, 1999, p. 118. 
ristika, kuri rodo, kiek mes galime būti tikri, kad nežinoma stebejjimo reikšmè bus tokia pati kaip moda):

$$
\sum_{i=1}^{\mathrm{n}} \mathrm{P} i^{2}
$$

P čia žymi tam tikros partijos ( $i$ ) vietų parlamente dalį, išreikštą santykiniu dažniu (pvz., 34 proc. būtų 0,34). Būtina pastebėti, kad L-T indeksas gali igauti minimalią 1 reikšmę. Tai reikštų, kad partinėje sistemoje egzistuoja tik viena efektyvi (reikšminga) partija. Maksimali L-T mato reikšmė, kai partinejje sistemoje yra n partijų, - n. Tai reikštų, kad visos partijos turi po lygiai vietų, taigi yra vienodai „efektyvios“ - pavyzdžiui, jų potenciali įtaka sudarant vyriausybę objektyviai turètų būti tokia pati. L-T indeksas patogus tuo, kad jis atsižvelgia ị partijų efektyvumą, kitaip tariant, $\mathfrak{i}$ faktą, kad skirtingų partijų ittaka ir reikšmè partinejje sistemoje skiriasi. Juo remiantis galima tiek ivertinti partinès sistemos fragmentacijos lygit, tiek nustatyti, kiek šis lygis yra stabilus (tai yra ịvertinti jos fragmentacijos svyravimus).

Konkurencija dèl vyriausybès vietu. G. Sartorio tipologijos taikymas padeda išplèsti partinès sistemos stabilumo sampratą ir matavimą, tačiau to neužtenka siekiant îvertinti vyriausybès formavimo lygmenyje egzistuojančius konkurencijos šablonus. Pavyzdžiui, net ir išliekant tam pačiam fragmentacijos ir poliarizacijos lygiui, konkuruojančių partijų blokų sudètis ir koalicijų alternatyvos gali būti labai nestabilios. Siekiant užpildyti šiuos trūkumus, straipsnyje taikoma P. Mairo partinių sistemų klasifikacijos pagal konkurenciją dèl vyriausybės vietų schema. Išskiriami trys kintamieji, pagal kuriuos nustatomas partijų konkurencijos dèl vyriausybès struktūros modelis: vyriausybės kaita, vyriausybės sudarymo alternatyvų naujumas/žinomumas ir partijų galimybè įeiti ị vyriausybès sudètį.

Vyriausybès kaita. Šis kintamasis gali igyti tris reikšmes: a) absoliutus vyriausybės pasikeitimas: visos partijos iš vyriausybės yra tam tikru laiko momentu „pašalinamos“ ir jų vietą užima naujos politinès jègos. Kitaip tariant, pagal partinę sandarą ministrų kabinetas atnaujinamas visiškai: geriausias pavyzdys - Didžioji Britanija, kur leiboristų kabinetą visuomet pakeičia 
konservatorių vyriausybė (ir atvirkščiai). Absoliutus vyriausybės pasikeitimas įmanomas ir tarp koalicijų, jeigu jos reprezentuoja du skirtingus konkuruojančius blokus; b) dalinis vyriausybès partinès sandaros pasikeitimas - naujojoje vyriausybejje lieka bent viena partija iš buvusios koalicijos; c) nèra kaitos (vyriausybę sudaro tos pačios partijos). ${ }^{32}$

Vyriausybes sudarymo alternatyvų naujumas/žinomumas. Šis kintamasis turi dvi galimas reikšmes: pirma, kai valstybejje egzistuoja stabilios partijų grupès, linkusios sudaryti vyriausybę kartu, ir, antra - tendencijos, kai atsiranda vis naujų partijų koalicijų. Geras stabilių partijų grupių pavyzdys - Airija iki 1993 metų („Fianna Fail“ vs kitų partijų koalicija). ${ }^{33}$

Partiju galimybe įeiti ị vyriausybés sudettị. Kas valdo? Šis kintamasis atskiria dvi situacijas: ar per tam tikrą laikotarpi visos partijos turejo galimybių patekti i vykdomają valdžią, ar tam tikros partijos nuolatos neįtraukiamos $\mathfrak{i}$ kabineto sudarymo procesą. ${ }^{34}$ Pavyzdžiui, Nyderlanduose dažniausiai visos partijos turi galimybių patekti ị valdžią, tačiau Čekijoje Komunistų partija niekada neįtraukiama ị vyriausybines koalicijas.

Pagal šiuos tris kintamuosius galima išskirti du idealius modelius (partinių sistemų tipus): atvira - nestabili ir uždara - stabili partinė sistema. Šie tipai atspindi dvi skirtingas partijų konkurencijos struktūras: neprognozuojama ir prognozuojama konkurencija. Atvira, arba, kitaip tariant, nestabili partinè sistema (su neprognozuojama struktūra), pasižymètų šiais bruožais: 1) daliniai vyriausybès pasikeitimai; 2) vyriausybès sudarymo alternatyvų nestabilumas; 3) visos reikšmingos partijos turi galimybę sudaryti kabinetą. Uždara, arba stabili, partiné sistema (su prognozuojama struktūra): 1) vyriausybių kaita arba visiška, arba jos nèra; 2) vyriausybės sudarymo alternatyvos per tam tikrą laikotarpi yra stabilios; 3 ) tam tikros partijos yra nuolatos neįtraukiamos ị kabineto sudarymo procesą. ${ }^{35}$

P. Mairo schema straipsnyje taikoma su vienu pataisymu - galima pa-

${ }^{32}$ Mair, P. Party System Change: Approaches and Interpretation. Oxford: Clarendon Press, 1997, p. 207-209.

${ }_{33}$ Ten pat, p. 209.

${ }^{34}$ Ten pat, p. 199-223.

${ }^{35}$ Ten pat, p. 199-223. 
stebèti, kad vienas iš stabilios - uždaros partinès sistemos kriterijų yra gana dviprasmiškas. Pagal P. Mairą partinė sistema, kurioje yra dvi tas pačias koalicijas visada sudarančios 4 partijos (taigi, koalicijos visiškai prognozuojamos, vyrauja absoliutus vyriausybės sudėties pasikeitimas), pasižymi nestabilumo bruožu - nèra reikšmingų partijų, kurios nuolatos neįtraukiamos ị kabineto sudarymo procesą. Tačiau taip teigti būtų netikslu, nes sistemos sąveikų šablonai akivaizdžiai stabilūs. Siūloma šią problemą išspręsti prie trečiojo kriterijaus pridedant sąlygą: „...arba tam tikroms partijoms nuolatos užkertamas kelias patekti i parlamentą ir tapti reikšmingomis“. Kitaip tariant, nustatant, ar partinè sistema stabili pagal trečiajji kriterijų, reikia atsižvelgti, ar tam tikroms partijoms užkertamas kelias ị vyriausybę. Jeigu ne, svarbu, ar naujos reikšmingos partijos patenka î parlamentą (jeigu ne - partinė sistema pagal ši požymị yra stabili).

\section{Lietuvos partinès sistemos stabilumas 1990-2010 m.}

Lietuvos partinė sistema užsienio autorių apibūdinama kaip „santykinai nestabili“ $:{ }^{36}$ politinèje arenoje nuolatos iškyla naujų reikšmingų partijų, tačiau galima pastebėti ir tam tikrą tęstinumą (buvusio režimo besireformavusios partijos ir opozicijos partijos-ipejdinès perskyros išlikimą). Straipsnyje mūsų šalies partinès sistemos stabilumo raida ịvertinama pagal antrajame skyriuje pateiktus matavimo būdus.

Rinkimu lygmuo. Rinkejjų elgsenos kaitumas, apskaičiuotas remiantis 1992-2008 m. Seimo rinkimų rezultatais daugiamandatèje apygardoje, rodo aukšto lygio Lietuvos partinès sistemos nestabilumą (žr. 1 pav.). Netgi lyginant su kitomis Vidurio ir Rytų regiono pokomunistinèmis šalimis Lietuva išsiskiria ir pagal šị rodiklị yra lyderè. 1994-2003 m. rinkèjų elgsenos kaitumo vidurkiai naujose ES valstybėse iš pokomunistinio bloko (išskyrus Lietuvą) svyravo tarp 19,5 (Čekija) ir 42,6 (Latvija) ${ }^{37}$, o

\footnotetext{
${ }^{36}$ Stojarová, V. Political parties in Central and Eastern Europe: In Search of Consolidation. Stockholm: International Institute for Democracy and Electoral Assistance, 2007, p. 56.

${ }^{37}$ Jungerstam-Mulders, S. Parties and Party Systems in Post-Communist EU Member States: Comparative Aspects. Post-Communist EU Member States: Parties and Party Systems. Edited by S. Jungerstam-Mulders (ed.). Ashgate, 2006, p. 1-22.
} 
Lietuvoje 1992-2008 m. periode rinkèjų elgsenos kaitumo vidurkis lygus 43,5. Reikètų pastebèti, kad $2008 \mathrm{~m}$. Seimo rinkimuose šis rodiklis pagaliau krito ir igijo mažiausią reikšmę per visą nepriklausomybès laikotarpi. Tačiau net ir 29,7 rinkèjų elgsenos kaitumas yra pakankamai nuo normos nukrypstantis įvertinimas. ${ }^{38}$

Kaip matyti 1 pav., Lietuvoje 1996 m. ir 2000 m. partiju pakeitimas paaiškino tik mažiau nei pusę bendro rinkejų elgsenos kaitumo. 2004 m. ir 2008 m. šis santykis pasikeitè - skirtumas tarp šių matų tik kiek didesnis nei 10 proc. Taigi, kitaip nei iki $2000 \mathrm{~m}$. imtinai, per pastaruosius dvejus parlamento rinkimus už didžiąją dalį partinès sistemos nestabilumo rinkimų lygmenyje yra atsakinga naujų partijų sèkmè.

1 pav. Rinkejjų elgsenos kaitumas ir partijų pakeitimas Lietuvoje 1996-2008 m. (apskaičiuota remiantis 1992-2008 m. Seimo rinkimų rezultatais daugiamandateje apygardoje)

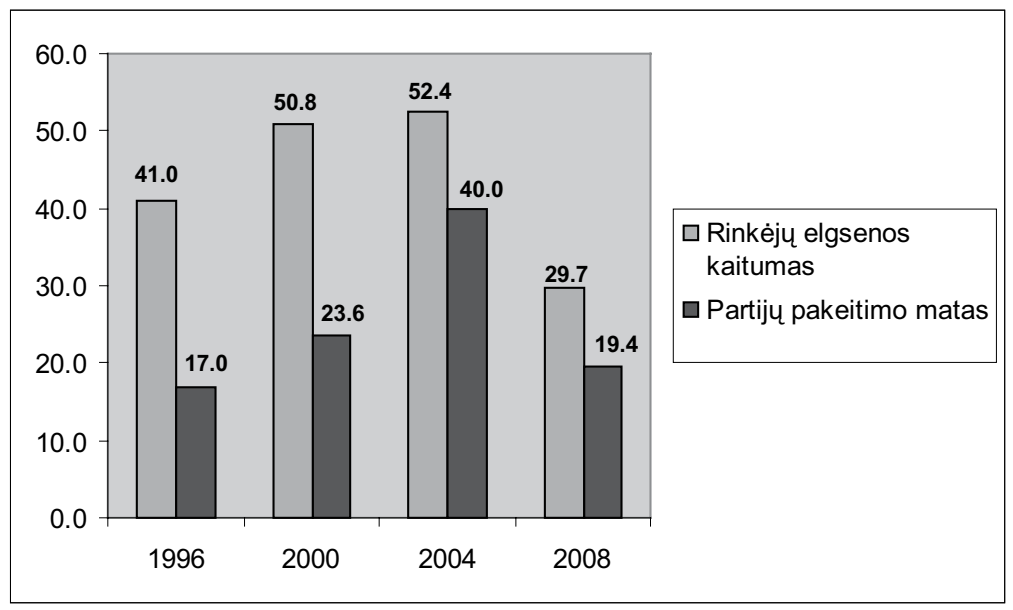

${ }^{38}$ P. Mairas (žr. Party System Change: Approaches and Interpretations, p. 80) nurodo, kad 1945-1989 m. Vakarų Europos partinèse sistemose vidutinis rinkèjų elgsenos kaitumas buvo 8,7. Šis skaičius gali būti traktuojamas kaip ,stabilumo standartas“. 
Rinkejjų elgsenos kaitumo ir partijų pakeitimo matai perskaičiuoti autoriaus, remiantis Lietuvos Respublikos vyriausiosios rinkimų komisijos informacija (www.vrk.lt) ir Ainès Ramonaitès duomenimis, naudotais S. Jungerstam-Mulders sudarytoje knygoje „PostCommunist EU Member States: Parties and Party Systems“.

Fragmentacija ir ideologinis atstumas. Taikant G. Sartorio reikšmingų partijų skaičiavimo kriterijų, 1992-1996 metų laikotarpiu (po trumpai trukusio Sąjūdžio dominavimo 1990-1992 m.) Lietuvos partinejje sistemoje ịsitvirtino penkios reikšmingos partijos: Tẻvynès Sąjunga (Lietuvos konservatoriai) (TS (LK), Lietuvos krikščionių demokratų partija (LKDP), Lietuvos centro sąjunga (LCS), tuometiné Lietuvos socialdemokratų partija (LSDP) ir Lietuvos demokratinè darbo partija (LDDP). Keturios iš jų turejjo dalyvavimo vyriausybeje patirties, o LSDP taip pat vertintina kaip turejjusi koalicinị potencialą. ${ }^{39}$

Situacija stipriai pasikeite 2000-ųjų parlamento rinkimuose, kurie iš esmès žymèjo naują Lietuvos partinès sistemos raidos etapą. Kai kurių autorių teigimu, po jų partineje sistemoje liko 3 reikšmingos partijos ${ }^{40}$, iš kurių 2 buvo naujos. ${ }^{41}$ Vis dèlto, turint galvoje, kad partijų reikšmingumas tiksliau ịvertinamas per ilgesnị laikotarpị, TS (LK) irgi turètų būti ittraukta ị reikšmingų partijų sąrašą. Vyriausybès koaliciją po $2000 \mathrm{~m}$. rinkimų formaliai sudarè (be Naujosios sąjungos ir Liberalų sąjungos) ir Moderniųjų krikščionių demokratų sąjunga (MKDS) bei Lietuvos centro sąjunga $(\mathrm{LCS})^{42}$, tačiau menkas šių partijų mandatų kiekis (atitinka-

${ }^{39}$ Krupavičius, A. Politiniai Seimo rinkimu '96 rezultatai ir vyriausybės formavimas: trečiasis „atmetimas“. Seimo rinkimai '96: „,trečiasis atmetimas “. Sudarė A. Krupavičius. Vilnius: Tvermè, 1998, p. 192.

${ }^{40}$ Naujoji sajunga (socialliberalai) NS(SL), Lietuvos liberalų sajunga (LLS) ir iš LDDP ir LSDP naujai sukurta LSDP.

${ }^{41}$ Novagrockienè, J. Seimo rinkimai 2000: partinès sistemos evoliucija ar transformacija. Lietuva po Seimo rinkimu 2000. Sudarė A. Jankauskas. Vilnius: Naujasis lankas, 2001, p. $55-56$.

42 Jankauskas, A., Žeruolis, D. Understanding politics in Lithuania. Aarhus: University of Aarhus, Demstar research report, 2004, No. 18, p. 12. 
mai - 3 ir 2$)^{43}$ verčia abejoti, ar jos buvo būtinai reikalingos vykdomajai valdžiai - jų ittraukimas veikiau traktuotinas kaip „naujosios politikos“ sąvokai papildomo svorio suteikęs veiksmas.

2004-2010 m. Lietuvos partinès sistemos fragmentacija pagal G. Sartorio kriterijus pastebimai išaugo: tai gerai iliustruoja, kad vyriausybès koalicijai nuolatos prireikia ne mažiau kaip 4 partijų. Faktiškai šiuo laikotarpiu Lietuvos politineje arenoje nuolatos veikè 7-9 reikšmingos partijos. ${ }^{44}$ Beveik visos jos turejo (turi) vyriausybinio valdymo patirties arba pasižymi iki šiol neišreikštu, tačiau neabejotinu koaliciniu potencialu: nesunku sumodeliuoti situaciją, kurioje partijos „Tvarka ir teisingumas“ gali prireikti vykdomosios valdžios formavimui. Taigi, 1992-2000 m. iš esmés nuosaikaus daugiapartiškumo klasei priklausiusi Lietuvos partinè sistema nuo 2004 m. aiškiai pasuko ekstremalaus daugiapartiškumo link.

Be to, Laakso-Taagepera indekso analizè patvirtina, kad Lietuva pasižymi fragmentacijos nestabilumu (žr. 1 lentelę). Fragmentacija buvo sumažèjusi 1996 m. (tai nesunkiai galima paaiškinti triuškinama tuometinès TS-LK pergale), tačiau nuo tada nuosekliai ir sparčiai didèjo. Palyginti su kaimynine Lenkija (žr. 2 lentelę), kur bendras fragmentacijos iverčio standartinis nuokrypis yra gerokai mažesnis (kitaip tariant, fragmentacijos ịverčių sklaida yra mažesnè $)^{45}$, Lietuvos partinė sistema šiuo atžvilgiu aiškiai demonstruoja nestabilumo tendencijas.

${ }^{43}$ Duomenys iš Lukošaitis, A. Koalicinès politikos patirtis ir perspektyvos Lietuvoje. Lietuva po Seimo rinkimu 2000. Sudare A. Jankauskas. Vilnius: Naujasis lankas, 2001, p. 71.

${ }^{44}$ Po 2004 m. parlamento rinkimų reikšmingoms priskiriamų partijų sąrašas: TS (LK), Darbo partija (DP), Liberalų ir centro sajunga (LiCS), Valstiečių ir naujosios demokratijos partijų sajunga (VNDS), LSDP, NS(SL) (pastarosios dvi partijos dalyvavo $2004 \mathrm{~m}$. kaip koalicija, tačiau pagal vėlesnius procesus vertinamos kaip dvi atskiros politinès jègos), Liberalų demokratų partija (LDP); vèliau - nuo DP atskilus Pilietinès demokratijos (PD) partijai, o nuo LiCS - Lietuvos Respublikos liberalų sajūdžiui, parlamente buvo galima užfiksuoti net 9 reikšmingas partijas. Po 2008 m. reikšmingoms priskiriama: TS-LKD, DP, LSDP, „Tvarka ir teisingumas“, Tautos prisikèlimo partija (TPP), LRLS ir LiCS; vèliau - nuo TPP atskilusių Seimo narių pagrindu susikūrus Krikščionių partijai, reikšmingų partijų skaičius padidèjo iki 8 .

${ }^{45}$ Atmetant 1991 m. rinkimus, kurie traktuotini kaip išskirtis: juose apskritai netaikytas rinkimų slenkstis, ir fragmentacija perženge 10 ribą. 
1 lentele. Lietuvos ir Lenkijos partinès sistemos fragmentacijos svyravimas pagal Laakso-Taagepera indeksą ${ }^{46}$

\begin{tabular}{|c|c|c|c|c|c|c|}
\hline & 1992 & 1996 & 2000 & 2004 & 2008 & $\begin{array}{c}\text { Standartinis } \\
\text { nuokrypis }\end{array}$ \\
\hline L-T indeksas & 4,05 & 3,3 & 4,2 & $5,5^{*}$ & 5,8 & 1,04 \\
\hline
\end{tabular}

* Indeksai skaičiuojami pagal politinių jègų mandatus po parlamento rinkimų. LSDP ir NS/SL, nors vèliau veikẻ kaip atskiros partijos, skaičiuojant indeksą traktuotos kaip viena politinè jèga, nes rinkimuose dalyvavo bendroje koalicijoje. Taip pat elgtasi ir $2000 \mathrm{~m}$. Socialdemokratinès koalicijos atveju.

2 lentele. Lenkijos partinès sistemos fragmentacijos svyravimas pagal Laakso-Taagepera indeksą

\begin{tabular}{|l|c|c|c|c|c|c|}
\hline & 1993 & 1997 & 2001 & 2005 & 2007 & $\begin{array}{c}\text { Standartinis } \\
\text { nuokrypis }\end{array}$ \\
\hline L-T indeksas & 3,9 & 2,9 & 3,58 & 4,26 & 2,8 & 0,64 \\
\hline
\end{tabular}

Ar didejanti Lietuvos partinès sistemos fragmentacija reiškia ir poliarizacijos tendencijas? Teigiama, kad 1990-1992 m. Lietuvos partiné sistema dèl didelio pagrindinių partijų abipusio priešiškumo buvo aiškiai poliarizuota. ${ }^{47}$ Visgi iki $2000 \mathrm{~m}$. parlamento rinkimų imtinai, taikant G. Sartorio kriterijus, aiškios poliarizacijos fiksuoti negalima. Radikalių politinių jėgų, turinčių ideologinio antisistemiškumo požymių, pasireiškimas Lietuvoje buvo labai ribotas; reikšmingų santykio antisistemiškumu pasižyminčių po-

${ }^{46}$ Fragmentacijos indeksai apskaičiuoti autoriaus pagal duomenis iš: Stojarová, V. Political parties in Central and Eastern Europe: In Search of Consolidation. Stockholm: International Institute for Democracy and Electoral Assistance, 2007; Lukošaitis, A. Koalicinès politikos patirtis ir perspektyvos Lietuvoje. Lietuva po Seimo rinkimu 2000. Sudare A. Jankauskas. Vilnius: Naujasis lankas, 2001; Lukošaitis, A. Moderniosios partinès sistemos formavimosi etapai Lietuvoje. Lietuvos politinés partijos ir partiné sistema (1 knyga). Sudarè A. Jankauskas, E. Kūris ir J. Novagrockienè. Kaunas: Naujasis lankas, 1997; interneto svetainių: $w w w . l r s . l t ;$;ww.vrk.lt.

${ }^{47}$ Novagrockienė, J. Lietuvos partinès sistemos raida. Seimo rinkimai '96: „,trečiasis atmetimas “. Sudarè A. Krupavičius. Vilnius: Tvermè, 1998, p. 310. 
litinių jègų taip pat nebuvo. ${ }^{48}$ Partinè sistema faktiškai funkcionavo dvipoliu pagrindu: centro kairè, kurioje dominavo LDDP, prieš centro dešinę, kurioje dominavo TS-LK.

Po 2000 m. sparčiai augant fragmentacijai, kai kurių autorių teigimu, Lietuvos partinè sistema pradejo judèti nuo nuosaikaus poliarizuoto daugiapartiškumo link: silpsta ịcentrinès tendencijos, egzistuoja potencialas abipusėms opozicijoms. ${ }^{49}$ Be to, tiek Darbo partija (DP), tiek „Tvarka ir teisingumas“ po $2004 \mathrm{~m}$. parlamento rinkimų galèjo būti traktuojamos kaip protesto prieš esamą politinę sistemą partijos. Būtina pastebėti, kad, skirtingai nei chrestomatinis tokios politinès jègos pavyzdys - Progreso partija Danijoje - DP iš karto buvo įtraukta ị vyriausybès formavimo procesą ir faktiškai tapo prosistemine politinè jèga, o tai sušvelnino sistemos poliarizacijos tendencijas.

„Tvarkos ir teisingumo“ atvejis yra sudètingesnis. Nepaisant kartais pasigirstančių siūlymų radikaliai keisti konstitucinę santvarką, partijos ideologija apskritai nèra priešiška demokratiniam režimui. ${ }^{50} 2004-2008$ m. partija atitiko santykio antisistemiškumo požymius: partinëje sistemoje ji buvo palyginti izoliuota, jos koalicinis potencialas žemas. Po $2004 \mathrm{~m}$. rinkimų opozicijos bendradarbiavimo sutartị sudariusios TS (LK) ir Liberalų ir centro sajunga ị ją neịtraukè tuo metu Liberalų demokratų partija besivadinusios „Tvarkos ir teisingumo“, taigi šalyje formaliai egzistavo dviguba opozicija. ${ }^{51}$ Panaši situacija atrodė susiklostanti ir po pastarųų rinkimų, kai socialdemo-

${ }^{48}$ Iš esmès LDDP 1992-1996 m. buvo izoliuota nuo kitų partijų, vengusių bendradarbiauti su ja. Tačiau ji, viena vertus, buvo vyriausybinè partija (valdymo laikotarpiu dèl Lietuvos demokratinės orientacijos abejonių nekilo); kita vertus, eventualiai konkurencinèje erdvèje priartejo prie kitų politinių jègų, tad tai buvo aiškiai prosisteminė partija.

${ }^{49}$ Jurkynas, M., Ramonaitè, A. Kairè ir dešinė Lietuvoje: ekspertu ir elektorato nesusikalbejjimas. Lietuva po Seimo rinkimu 2004. Sudarė A. Jankauskas. Vilnius: Naujasis lankas, 2005, p. 74.

${ }^{50}$ Partijos įstatuose aiškiai išreikštas lojalumas šalies demokratinei sistemai: ,Partija Tvarka ir teisingumas (toliau - Partija) yra Lietuvos Respublikos politinė partija, teigianti laisvos ir liberalios demokratinès visuomenès idejas" (http://www.ldp.lt/lt/istatai).

${ }^{51}$ Ivaškevičius, A. „Tryliktoji vyriausybe““ pradeda darbą. Kauno diena, 2004. Interneto prieiga: http://kauno.diena.lt/dienrastis/kita/tryliktoji-vyriausybe-pradeda-darba-24320 (žiūrèta 200905 10). 
kratai formalią opozicijos koaliciją sudarè su DP, buvusius liberaldemokratus vèl palikdami „už borto“ ${ }^{52}$ Tačiau neilgai trukus DP su „Tvarka ir teisingumu“ sudare naują opozicijos sutartį, taip i ’ "antrąją opoziciją “ nustumdami socialdemokratus.

Taigi, nors abipusių opozicijų reiškinys formaliai lyg ir išlieka (tačiau yra beformis, nes opozicijų sudètinès dalys keičiasi), Lietuvos partinę sistemą sunkiai būtų galima įvardyti bent kaip „pusiau poliarizuotą“. Tikros santykio antisisteminès partijos neegzistuoja, visos reikšmingos partijos turi daugiau ar mažiau koalicinio potencialo, o abipusės opozicijos veikiau atsiranda dèl trumpojo laikotarpio partijų interesų nei dèl tam tikrų partijų santykio antisistemiškumo. Nors Lietuvos partinè sistema aiškiai pasislinko nuo riboto iki ekstremalaus daugiapartiškumo klasès, poliarizacijos kaita nèra vienareikšmiška: taikant antrajame skyriuje pateiktus kriterijus, net ir dalinę tikrą poliarizaciją fiksuoti būtų netikslu. Vis dèlto aišku, jog partinė sistema nebefunkcionuoja pagal nuosaikaus daugiapartiškumo mechaniką - negalima teigti, kad konkurencija paremta dviem tarpusavyje konkuruojančiais poliais, nes partinei sistemai būdingas polinkis $\mathfrak{i}$ abipuses opozicijas.

Konkurencija dèl vyriausybès vietų. Konkurenciją dèl vyriausybès pradedant tirti nuo pirmųjų tikrai daugiapartinių Lietuvos parlamento rinkimu, ${ }^{53}$ 1992-2000 m. laikotarpiu galima fiksuoti besiformuojančius stabilius sąveikų šablonus: kaip ir Vengrijos (bei Čekijos) atveju, dèl natūralių priežasčių koalicijos buvo anksčiau politinëje arenoje nematytos, tačiau pakankamai prognozuojamos (LDDP prieš centro dešinès partijas). Vyriausybių kaita buvo absoliuti (arba jos nebuvo), o $1996 \mathrm{~m}$. ̨̇ parlamentą nepateko nè viena nauja reikšminga partija, taigi, atrodè, kad, vertinant pagal šiuos kriterijus, partinè sistema užsidaro.

Tuo tarpu 2000 m. parlamento rinkimai žymèjo konkurencijos struktū-

52 „Bernardinai.lt“, Socialdemokratai ir Darbo partija sudaré opozicijos koaliciją, o lyderiu paskyrė G. Kirkilą. Bernardinai.lt, 2009. Interneto prieiga: http://www.bernardinai.lt/ index.php?url=articles/87934 (žiūrèta 200905 15).

${ }^{53}$ Krupavičius, A. Politiniai Seimo rinkimu '96 rezultatai ir vyriausybès formavimas: trečiasis ,,atmetimas“. Seimo rinkimai '96: „, trečiasis atmetimas “. Sudarė A. Krupavičius. Vilnius: Tvermè, 1998, p. 181. 
ros stabilizacijos tendencijų išnykimą. Nuo $2000 \mathrm{~m}$. koalicijų alternatyvos tapo itin neprognozuojamos: pirma, per kiekvienus parlamento rinkimus iškyla naujų reikšmingų politinių jègų, kurios patenka ị parlamentą ir vyriausybę; antra, didejjanti fragmentacija lemia vis naujas politinių aljansų konfigūracijas. Vyriausybių kaitoje nuo 2000 m. neginčijamai dominuoja dalinis būdas. ${ }^{54}$ Vertinant trečiąj kriterijų reikia pastebèti, kad $2003 \mathrm{~m}$. susikūrusiai partijai „Tvarka ir teisingumas“ (iš pradžių besivadinusiai Liberalų demokratų partija) kelias ił vyriausybę kol kas užkertamas. Tad, kaip buvo anksčiau minèta, tai gali būti labai laikinas reiškinys, be to, naujos reikšmingos partijos Lietuvoje nuolatos patenka tiek ị vyriausybę, tiek ị parlamentą. Todèl nuo $2000 \mathrm{~m}$. Lietuvos partinè sistema pagal visus tris vidinio nestabilumo bruožus turètų būti traktuojama kaip atvira - nestabili.

Lietuvos partinès sistemos stabilumo raidos santrauka pagal straipsnyje analizuotus lygmenis pateikiama 3 lentelèje. Išskiriami du pagrindiniai raidos etapai: 1) nuo 1990 iki 2000 m. - stabilumo bruožų turintis periodas; 2) nuo $2000 \mathrm{~m}$. iki dabar - partinė sistema tapo aiškiai nestabili visuose trijuose lygmenyse.

3 lentele. Lietuvos partinès sistemos stabilumo raida

\begin{tabular}{|c|c|c|}
\hline & $1990-2000 \mathrm{~m}$. & $2000-2010 \mathrm{~m}$. \\
\hline $\begin{array}{l}\text { Rinkimu } \\
\text { lygmuo }\end{array}$ & $\begin{array}{l}\text { Aukštas nestabilumo lygis; } \\
\text { naujų partijų sėkmé paaiškina } \\
\text { mažiau nei pusę rinkejjų elg- } \\
\text { senos kaitumo }\end{array}$ & $\begin{array}{l}\text { Aukštas nestabilumo lygis*; } \\
\text { naujos partijos atsakingos už } \\
\text { didžiają dali rinkejjų elgsenos } \\
\text { kaitumo }\end{array}$ \\
\hline $\begin{array}{l}\text { Fragmentaci- } \\
\text { ja ir ideologi- } \\
\text { nis atstumas }\end{array}$ & $\begin{array}{l}\text { Besiformuojantis nuosaikus } \\
\text { daugiapartiškumas }\end{array}$ & $\begin{array}{l}\text { Kaita iš neįsitvirtinusio riboto } \\
\text { i ekstremalų daugiapartizmą } \\
\text { su poliarizacijos požymiais }\end{array}$ \\
\hline $\begin{array}{l}\text { Konkurencija } \\
\text { dèl vyriausy- } \\
\text { bės vietų }\end{array}$ & $\begin{array}{l}\text { Polinkis į visų } 3 \text { kriterijų sta- } \\
\text { bilizaciją }\end{array}$ & \begin{tabular}{|l} 
Destabilizuota konkurencijos \\
struktūra ( 3 iš 3 atviros parti- \\
nės sistemos bruožų)
\end{tabular} \\
\hline
\end{tabular}

* Per pastaruosius Seimo rinkimus (2008 m.) rinkejjų elgsenos kaitumas pastebimai sumažèjo, nors lyginamojoje perspektyvoje išlieka pakankamai aukštas.

${ }^{54} 2001 \mathrm{~m}$. pasikeitus Vyriausybei, joje liko socialliberalai; $2004 \mathrm{~m}$. - socialliberalai ir socialdemokratai; 2006 m. - socialdemokratai, valstiečiai liaudininkai ir, skilus DP, atsiradusi PD partija, $2008 \mathrm{~m}$. - Liberalų ir centro sajunga. 


\section{Išvados}

1. Rinkejų elgsenos kaitumo ir partijų pakeitimo analizė Lietuvos atveju atskleidžia, kad rinkimų lygmenyje Lietuvos partinè sistema per 1990-2010 m. laikotarpi pasižymėjo labai aukštu ir nuolat augančiu nestabilumo lygiu, kuris gerokai smuko tik per naujausius parlamento rinkimus. 1992-2000 m. partijų pakeitimas paaiškino mažiau nei pusę bendro rinkimų nestabilumo. Pastaraisiais metais tendencijos pasikeitè, ir rinkimų nestabilumą daugiausia lemia būtent naujų partijų sėkmè, o ne balsų persiskirstymas tarp iki konkrečių parlamento rinkimų partinèje sistemoje jau veikusių politinių jẻgų.

2. 1990-2000 m. situacija Lietuvos partinejje sistemoje buvo artima besiformuojančiam nuosaikiam daugiapartiškumui. Antrasis stabilumo raidos etapas (nuo $2000 \mathrm{~m}$. iki dabar) parodé, kad šis tipas Lietuvoje neįsitvirtino. Viena vertus, sparčiai pradejjo plèstis fragmentacija - šiuo metu partinèje sistemoje jau veikia apie 8 reikšmingas partijas. Poliarizacijos požymiai nèra aiškiai išreikšti, tačiau konkurencinès erdvės nebegalima priskirti nuosaikiam daugiapartiškumui, kuris funkcionuoja dvipolès konkurencijos pagrindu.

3. Konkurencijos dèl vyriausybės vietų aspektu Lietuvos partinès sistemos ịvertinimas yra analogiškas. Po $1996 \mathrm{~m}$. parlamento rinkimų atrodè, kad partinè sistema linksta ị uždarumą ir visų trijų kriterijų stabilizaciją, tačiau 2000-2010 m. konkurencijos struktūra tapo visiškai destabilizuota ( 3 iš 3 aiškiai išreikštų atviros partinès sistemos bruožų).

4. Skirtingų tyrimo instrumentų patobulinimas ir taikymas Lietuvos atveju patvirtina, kad partinès sistemos stabilumas yra daugiadimensinis reiškinys. Nors iš pirmo žvilgsnio atrodo, kad visų trijų pagrindinių teorinių prieigų taikymas aiškiai rodo nestabilumą, gilesnè analizė atskleidžia speficinius skirtumus tarp raidos etapų ir skirtingų stabilumo dimensijų. Kaip buvo minėta, 1990-2000 m. partinė sistema pasižymèjo labai aukštu rinkimų nestabilumu, tačiau naujų partijų sẻkmẻ buvo ribota, o kituose lygmenyse buvo galima ižvelgti stabilizacijos tendenci- 
jas (besiformuojantis aiškus partinès sistemos tipas, $\mathfrak{i}$ uždarą linkstanti konkurencija dèl vyriausybès). Tik vèliau nestabilumas (nuo $2000 \mathrm{~m}$. imtinai) aiškiai persidavė ir ị kitus lygmenis. Vadinasi, partinių sistemų stabilumo tyrimuose siekiant tikslių ir patikimų rezultatų reikètų taikyti skirtingų lygmenų stabilumą matuojančius instrumentus.

\title{
CONCEPTION AND MEASUREMENT OF PARTY SYSTEM STABILITY: SITUATION OF LITHUANIA IN 1990-2010
}

\author{
MAŽVYDAS JASTRAMSKIS
}

\section{Summary}

Keywords: party system; party system stability; electoral volatility; party replacement; fragmentation; ideological distance; relevant party; polarization; anti-system party; competition for government seats.

Party system stability is an important prerequisite for effective functioning of the democratic political system. Moreover, party system stability specifically influences functioning of the parliament institution. In Lithuania's context it raises a question - has our party system ever been close to the desired stability through the independence period, or has the instability level always been a negative factor for the effective parliament work?
Party system stability is treated as multidimensional phenomena: since party systems function at electoral, parliament and governmental levels, stability should be also analyzed in each of them. Therefore the aim of this article is to evaluate the development of Lithuania's party system stability in 1990-2010, while applying theoretical approaches that emphasize different dimensions of stability. 
3 main tasks are implemented in order to reach this aim: 1) to define a concept of party system; 2) to form a conception of the party system stability and delineate instruments for measuring it; 3 ) to apply the formed research tools for the Lithuania's situation. Three theoretical models (and instruments of party system measurement related with them) are discussed, modified and applied for the completion of these tasks: party system typology of G. Sartori, M. Pedersen's electoral volatility index and P. Mair's scheme of party competition for government seats.

Four main conclusions are reached in this article: 1) electoral volatility in Lithuania was high trough all inde- pendence period and dropped significantly only in last parliament election (however, it is still substantially high); 2) in period 1990-2000 Lithuania's party system's state could be described as moderate pluralism in the making, but since 2000 increase of fragmentation and emergence of bilateral oppositions has changed this tendency; 3 ) in period 1990-2000 party system was leaning towards closing of competition structure, but since 2000 it has became completely instable; 4 ) the case of Lithuania confirms that party system stability is multidimensional phenomena: instability in one level doesn't necessary reflect strictly same tendencies of instability in other levels. 